\title{
IMPLIKATUR PERCAKAPAN DALAM GELAR WICARA INDONESIA LAWAK KLUB
}

\author{
Santi Kurnia' ${ }^{1}$ Zainal Rafli², Miftahulkhairah Anwar ${ }^{3}$ \\ Pascasarjana Universitas Negeri Jakarta \\ ${ }^{1}$ santikurnia3391@gmail.com
}

\begin{abstract}
Abstrak
Penelitian ini bertujuan untuk menjelaskan jenis implikatur dan pelanggaran prinsip kerja sama dalam percakapan gelar wicara "Indonesia Lawak Klub". Penelitian ini merupakan jenis penelitian kualitatif dengan metode analisis isi, yakni cara mengumpulkan data, mengolah data, menganalisis data, dan menyajikan data secara objektif mengenai jenis implikatur dan pelanggaran prinsip kerja sama dalam percakapan gelar wicara "Indonesia Lawak Klub". Penelitian ini menghasilkan temuan 100 percakapan. Dari 100 percakapan tersebut terdapat 100 data yang mengandung jenis implikatur dan 120 data yang mengandung pelanggaran prinsip kerja sama. 100 data jenis implikatur terdiri atas 52 data atau $52 \%$ implikatur konvensional dan 48 data atau $48 \%$ implikatur percakapan, sedangkan, 120 data pelanggaran prinsip kerja sama terdiri atas 23 data atau 19,2\% pelanggaran prinsip kerja sama maksim kualitas, 60 data atau $50 \%$ pelanggaran prinsip kerja sama maksim kuantitas, 27 data atau 22,5\% pelanggaran prinsip kerja sama maksim relevansi, dan 10 data atau 8,3 pelanggaran prinsip kerja sama maksim cara.
\end{abstract}

Kata Kunci: Pragmatik, Implikatur, Prinsip Kerja Sama, Gelar Wicara

\begin{abstract}
This research is intended to elaborate the violation of the implicature and cooperation principles in the talk show of "Indonesia Lawak Klub". The research is a type of qualitative research using content analysis method by collecting, processing, analyzing, and presenting data objectively about the implication and principle violation of the cooperation of "Indonesia Lawak Klub" talk show. This reaserch had produced a discovery of 100 talks. From 100 talks there are 100 contents that contain the sort of implicature and 120 data contain the violation of the principles of cooperation. 100 sorts of implicature data comprises 52 data or $52 \%$ conventional implicature and 48 data or $48 \%$ talks of implicature. Whereas, 120 data about the violation of the principles of cooperation comprises 23 data or 19,2\% about cooperation principles violation in a maxim quality, 60 data or 50\% having cooperation principles violation in a maxim quantity,27 data or 22,5\% having cooperation principles violation in a maxim relevance, and 26 data or $8,3 \%$ including cooperation principles violation in a maxim way.
\end{abstract}

Keywords: Pragmatics, Implicature, Ccooperation principles, Talk Show

\section{PENDAHULUAN}

Bahasa sebagai alat komunikasi memberikan dampak di berbagai aspek kehidupan manusia. Salah satu dampak penting dari bahasa, yaitu terciptanya kegiatan interaksi berdimensi sosial sebagai hasil dari aktivitas bertutur.
Aktivitas bertutur dapat berjalan dengan baik jika penutur dan petutur terlibat secara aktif di dalamnya, begitu pun sebaliknya. Selain itu, bahasa juga menjadi jembatan dalam berkomunikasi guna tercapainya suatu kesepakatan 
terhadap suatu hal, baik secara lisan maupun tulisan

Komunikasi muncul dan berkembang seiring dengan besarnya manfaat yang didapatkan manusia. Komunikasi bisa dipandang sebagai sebuah kombinasi tindakan sadar untuk menyampaikan maksud dan tujuan. Komunikasi bukan hanya sekadar peristiwa, tetapi rancangan untuk mendatangkan efek bagi penutur dan petutur.

Komunikasi tidak selamanya dapat dipahami secara baik oleh petutur. Dalam proses interpretasi, pengaplikasian pemahaman secara semantis saja tidaklah cukup karena pesan yang disampaikan tidak hanya bersifat tersurat, tetapi juga tersirat. Munculnya fenomena pemaknaan bahasa menjadi rumit karena selain menggunakan bahasa konotatif, juga karena pemaknaan bahasa yang dipengaruhi konteks pemakainya. Fenomena tersebut jelas menunjukkan bahwa antara konteks dan latar belakang pengetahuan yang dimiliki oleh penutur dan petutur harus sama.

Sebuah kajian bahasa yang tidak dapat dilakukan tanpa mempertimbangkan konteks adalah kajian pragmatik. Konteks dalam kaitan kajian pragmatik merupakan hal penting dan kunci utama karena pragmatik mengkaji kaitan masalah pemaknaan dan perilaku pemakaian bahasa dalam konteks tempat munculnya data.

Yule menambahkan bahwa pragmatik terdiri atas tiga hal pengkajian, yaitu pengkajian terhadap makna, pengkajian makna bahasa berdasarkan pada konteksnya, pengkajian makna yang dikomunikasikan oleh penutur, dan pengkajian bentuk ekspresi menurut jarak sosial yang membatasi partisipasi yang terlibat dalam percakapan tertentu (Yule, 1996: 3).
Menurut Yule tersebut jelas bahwa pragmatik tidak sama dengan semantik, tetapi salah satu ilmu yang mengkaji makna berdasarkan istilah semiotik dan peran konteks saat berkomunikasi. Peran konteks tersebut melahirkan makna yang tidak sekadar pada hal yang tersurat, tetapi juga terdapat makna tersirat dan imperatif.

Salah satu konsep penting dalam pragmatik untuk mengkaji kebermaknaan suatu percakapan berdasarkan konteks adalah implikatur. Grice mengemukakan bahwa implikatur adalah preposisi atau pernyataan implikatif, yaitu apa yang mungkin diartikan, disiratkan, atau dimaksudkan oleh penutur, yang berbeda dari apa yang sebenarnya dikatakan oleh penutur di dalam suatu percakapan (Grice, 1991: 43). Sesuatu yang berbeda dari apa yang sebenarnya dikatakan merupakan maksud lain yang telah dikatakan secara eksplisit tersebut yang dapat berupa perintah atau anjuran atau hal lainnya yang bersifat implikatif dari makna tersirat ujaran tersebut.

Grice menyatakan bahwa ada dua macam jenis implikatur, yaitu (1) conventional implicature (implikatur konvensional) dan (2) conversation implicature (implikatur percakapan). Implikatur konvensional mengandung implikasi yang diperoleh langsung dari makna kata (yang didengar) bukan dari prinsip percakapan. Implikatur konvensional adalah makna yang dipahami atau diharapkan pada bentukbentuk bahasa tertentu, tetapi tidak terungkap. Artinya, implikatur konvensional adalah makna harfiah seperti yang dinyatakan oleh elemen kalimat secara format structural, sedangkan implikatur nonkonvensional adalah tindak ilokusi yang implikasi pragmatiknya diambil dari prinsipprinsip percakapan. Implikatur nonkonvensional inilah yang saat ini 
dikenal dengan sebutan implikatur percakapan. Implikatur percakapan adalah makna yang dipahami, tetapi tidak atau kurang terungkap dalam ucapannya (Kridalaksana, 1985).

Istilah implikatur muncul berdasarkan fenomena bahwa dalam pertuturan antara penutur dan petutur diharuskan untuk mematuhi kaidahkaidah prinsip percakapan. Namun, pada praktis pertuturan, baik disengaja atau tidak, antara penutur dan petutur melanggar prinsip percakapan tersebut, khususnya prinsip kerja sama. Pelanggaran prinsip kerja sama tersebut menimbulkan terjadinya implikatur percakapan (Brown \& Yule, 1983: 31). Proses interpretasi pada implikatur percakapan yang melanggar prinsip kerja sama tersebut berdasarkan situasi dan konteks. Pemahaman pada situasi dan konteks ujaran akan memberikan makna tepat yang terimplisit dalam ujaran tersebut.

Prinsip kerja dalam pragmatik, yang terkenal salah satunya adalah prinsip kerja sama yang dikemukakan oleh Grice sebagai nasihat bagi penutur dan petutur di dalam percakapan. Prinsip kerja sama adalah prinsip yang mengatur bagaimana hendaknya pembicaraan atau penutur bekerja sama dengan petutur agar percakapan bersifat kooperatif (Grice, 1991: 45). Rumusan kerja sama tersebut berbunyi sebagai berikut: "Make your conversational contribution such as required, at the stage at whice it occurs, by the accepted purpose of direction of the talk axchange in whice you are engaged. "(Nadir, 2013: 24).

Kontribusi dalam tuturan tersebut tentulah sudah sesuai dengan kebutuhan yang dimaksudkan. Tuturan tersebut menunjukkan bagaimana keberlangsungan prinsip kerja sama dalam sebuah tuturan. Melalui prinsip kerja sama, setidaknya tuturan tersebut dimaksudkan agar komunikasi dapat berlangsung dengan efisien.

Prinsip kerja sama terdiri atas empat maksim, yaitu (1) maksim kualitas; (2) maksim kuantitas; (3) maksim relevansi; dan (4) maksim cara. Menurut Levinson maksim kualitas berupa memberikan kontribusi tuturan yang benar. Maksim kuantitas berupa memberikan informasi yang cukup, relatif memadai, dan seinformatif mungkin. Maksim relevansi berupa memberikan jawaban yang relevan. Maksim cara berupa memberikan kontribusi yang tidak membingungkan, tidak bersifat ambigu, singkat, dan teratur (Levinson, 1983: 97-98).

Pada kenyataannya, dalam sebuah percakapan juga terdapat tuturan yang tidak menerapkan prinsip kerja sama, khususnya pada percakapan yang mengandung humor. Wijana menjelaskan bahwa dari sudut pandang linguistik, humor dikembangkan dari konsep ketidaksejajaran (incongruity) dan pertentangan (conflict) (Wijana, 2003: 132). Ketidaksejajaran dan pertentangan tersebut terjadi karena tuturan homor muncul atas pelanggaran terhadap prinsip dan kaidah bahasa. Meskipun demikian, dalam konumikasi pesan humor tetap tersampaikan secara informatif.

Humor memiliki peranan yang sentral dalam kehidupan manusia, yaitu sebagai sarana hiburan dan pendidikan untuk meningkatkan kualitas hidup manusia. Selain itu, humor dapat dijadikan pelipur lara dan hiburan yang menyenangkan. Semantara itu, dalam situasi masyarakat yang terdegradasi, humor dapat dijadikan sarana kritik sosial yang tajam, tetapi mampu menimbulkan efek kelucuan. Masyarakat penikmat humor akan mengalami dua hal sekaligus, yaitu terhibur dan tercerahkan. 
Dalam perkembangan terakhir ini banyak sekali acara televisi yang menghadirkan tontonan humor yang cukup membawa para penontonnya terhibur dan merasa tersentil terhadap fenomena-fenomena yang bermunculan di sekitar. Salah satu program televisi yang menyampaikan kritik secara humor adalah Indonesia Lawak Klub (ILK). Indonesia Lawak Klub (ILK) merupakan sebuah program televisi parodi Indonesia Lawyer Club. Program televisi yang memiliki jargon "jujur dan nyeleneh, menyelesaikan masalah tanpa solusi dan memberikan solusi tanpa ada masalah", berupa diskusi yang digulirkan secara mengalir dan lancar meski terdapat ketidaknyambungan, tetapi tetap terdapat diskusi serius yang sesuai dengan tema yang ditentukan.

Berbeda dengan program lawaklawakan lainnya yang menggunakan cercaan, sindiran bahkan hinaan terhadap lawan mainnya sebagai bahan humor, gelar wicara Indonesia Lawak Klub berkonsep acara forum diskusi humor yang mempertemukan para pelawak Indonesia dan membahas sebuah topik yang tengah menjadi isu terkini. Orang-orang yang biasanya melawak di atas panggung kini berkolaborasi membicarakan suatu masalah dalam bentuk diskusi dan berusaha untuk memberikan solusi dengan versi yang menghibur.

Berbagai peristiwa yang dewasa ini terjadi, termasuk kisruh di lingkungan pemerintahan tidak lepas dari sorotan masyarakat. Hal itu yang biasanya sering menjadi topik utama dalam kritik sosial masyarakat. Kritik sosial tersebut dapat disampaikan secara langsung ataupun tidak langsung, yakni dalam bentuk humor atau lelucon. Kritik sosial yang membicarakan sebuah bencana, kekhawatiran masyarakat terhadap lingkungan, kasus-kasus yang menjerat pejabat, dan berbagai kasus kriminal kerap kali dijadikan bahan humor oleh pelaku humor.

Tuturan-tuturan humor yang terjadi dalam gelar wicara Indonesia Lawak Klub tentu telah melakukan ketidaksejajaran dan pertentangan terhadap prinsip dan kaidah bahasa. Pelanggaran-pelanggaran yang dilakukan pada prinsip kerja sama, baik maksim kuantitas, kualitas, relevansi, dan cara juga sering kali ditemukan dan hal tersebut merupakan hal yang disengaja demi lucunya tuturan yang dihasilkan.

Untuk memperkuat latar belakang yang telah dijelaskan, dua artikel relevan yang telah diterbitkan berikut ini juga dijadikan tambahan rujukan yang valid. Pertama, penelitian yang ditulis oleh Mulya Tiara Fauziah, Emzir, dan Ninuk Lustyantie dengan judul Pelanggaran Prinsip Kerja Sama dalam Tuturan Diskusi Kelas Bahasa Indonesia (Fauziah, Emzir, \& Lustyantie, 2018). Penelitian tersebut mengungkapkan bahwa pelanggaran prinsip kerja dalam tuturan diskusi kelas Bahasa Indonesia, yaitu pelanggaran maksim kuantitas sebanyak tujuh tuturan, pelanggaran maksim kualitas sebanyak lima tuturan, palanggaran maksim relasi sebanyak tujuh belas tuturan, dan pelanggaran maksim cara sebanyak empat belas tuturan.

Kedua, penelitian yang ditulis oleh Hikmah Wahyuningsih dan Zainal Rafli dengan judul Implikatur Percakapan dalam Standup Comedy 4 (Wahyuningsih \& Rafli, 2017). Hasil dari penelitian tersebut adalah (1) berdasarkan data yang telah dianalisis, diperoleh jenis implikatur, yaitu 41 implikatur percakapan dan 33 implikatur konvensional; (2) berdasarkan data yang telah dianalisis maka 19 data yang termasuk ke dalam sifat implikatur daya batal, 5 data yang termasuk ke dalam sifat implikatur daya pisah, dan 50 data 
yang termasuk ke dalam sifat implikatur daya kalkukabilitas; dan (3) berdasarkan data yang telah dianalisis terbagi dalam 13 data yang termasuk dalam maksim kualitas, 40 data yang termasuk dalam maksim kuantitas, 10 data yang termasuk dalam maksim relevansi, dan 19 data yang termasuk dalam maksim cara.

Adapun kebaharuan penelitian ini adalah pada kajian analisis yang lebih kompleks, yakni pengkajian pada jenis implikatur yang terdiri atas implikatur percakapan dan implikatur konvensional, dan kajian pelanggaran prinsip kerja sama yang terdiri atas maksim kualitas, kuantitas, relevansi, dan cara. Penelitian-penelitian sebelumnya hanya mengkaji pada implikatur percakapan dan penggunaan prinsip kerja sama.

Berdasarkan penjelasan di atas, peneliti mencoba menggali tentang implikatur dan pelanggaran prinsip kerja sama dalam percakapan gelar wicara Indonesia Lawak Klub. Penelitian ini diharapkan mampu menjelaskan dan mendeskripsikan implikatur dan pelanggaran prinsip kerja sama, serta makna yang terkadung dalam percakapan gelar wicara Indonesia Lawak Klub.

\section{METODE PENELITIAN}

Penelitian ini merupakan penelitian kualitatif, dengan cara mengumpulkan data, mengolah data, menganalisis data, dan menyajikan data secara objektif mengenai jenis implikatur dalam percakapan gelar wicara Indonesia Lawak Klub. Adapun pendekatan yang digunakan dalam penelitian ini adalah pendekatan kualitatif dengan menggunakan metode analisis isi (content analysis). Menurut Krippendorff, analisis isi adalah sebuah kajian mendalam untuk membuat inferensi-inferensi yang dapat ditiru (replicable) dan sahih data dengan memperhatikan konteksnya (Krippendorff, 1991: 15).

Pengumpulan data dilakukan selama enam bulan, yaitu mulai Januari sampai dengan Juni 2017 sehingga terkumpul 48 tayangan. Berdasarkan korpus data tersebut kemudian dipilih sebanyak 18 tayangan yang akan dipakai sebagai sumber data pada penelitian ini. Adapun episode tersebut, yaitu episode 1 pada Minggu, 8 Januari 2017 dengan judul 17 Tahun Wali Band; episode 2 pada Sabtu, 14 Januari 2017 dengan judul Transportasi; episode 3 pada Minggu, 15 Januari 2017 dengan judul Serbuan Pekerja Tiongkok; episode 4 pada Minggu, 5 Februari 2017 dengan judul Muda va Tua; episode 5 pada Sabtu, 18 Februari 2017 dengan judul Spesial Armada Band; episode 6 pada Minggu, 26 Februari 2017 dengan judul Cerita Cinta; episode 7 pada Minggu, 5 Maret 2017 dengan judul Indonesia Cantik; episode 8 pada Minggu, 16 Maret 2017 dengan judul Cantik dengan Karya yang Cantik; episode 9 pada Minggu, 19 Maret 2017 dengan judul Emak-emak di Dunia Media Sosial; episode 10 pada Sabtu, 8 April 2017 dengan judul Cinta itu Membunuhku; episode 11 pada Minggu, 16 April 2017 dengan judul Impersonator; episode 12 pada Minggu, 30 April 2017 dengan judul Para Petualang Cantik; episode 13 pada Minggu, 14 Mei 2017 dengan judul Cinta dan Komitmen; episode 14 pada Minggu, 21 Mei 2017 dengan judul BPJS (Budget Pas-pasan, Jiwa Sosialita); episode 15 pada Sabtu, 27 Mei 2017 dengan judul Kejar Rezeki atau Ibadah; episode 16 pada Sabtu, 3 Juni 2017 dengan judul Hello Dangdut; episode 17 pada Sabtu, 10 Juni 2017 dengan judul Indonesia Beragam bukan Seragam; dan episode 18 pada Minggu, 18 Juni 2017 dengan judul Pilih Mana. 


\section{HASIL DAN PEMBAHASAN}

\section{Jenis Implikatur dan Penyimpangan Maksim Kerja Sama}

Percakapan-percakapan

humor dikreasikan dan dibentuk dari jenis implikatur dan penyimpangan prinsip kerja sama sehingga secara sengaja atau tidak sengaja peserta percakapan terlibat dalam proses komunikasi yang tidak wajar. Dalam percakapan nonhumor penutur dan petutur selalu memperhatikan maksim-maksim dalam percakapannya. Hal ini sangat berbeda dengan percakapan humor.

Jenis implikatur terdiri atas implikatur konvensional dan implikatur percakakan, sedangkan prinsip kerja sama yang disimpangkan tersebut meliputi empat maksim, yaitu maksim kualitas, maksim kuantitas, maksim relevansi, dan maksim cara. Berikut ini akan dipaparkan temuan tentang implikatur dan pelanggaran prinsip kerja sama dari keempat maksim tersebut.

\section{Jenis Implikatur}

Secara umum jenis implikatur terbagi dalam dua macam, yaitu implikatur konvensional dan implikatur percakapan. Dalam gelar wicara Indonesia Lawak Klub ditemukan 52 data atau 52\% mengandung implikatur konvensional dan 48 data atau $48 \%$ mengandung implikatur percakapan.

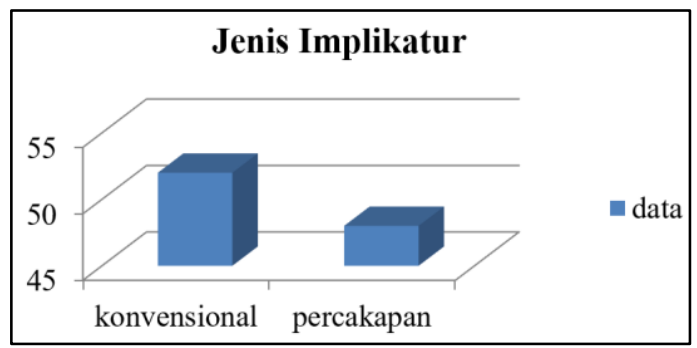

Grafik 1 Hasil Temuan Jenis Implikatur

Berikut adalah contoh gambaran jenis implikatur, yaitu implikatur konvensional dan implikatur percakapan.

\section{Implikatur Konvensional}

Implikatur konvensional adalah makna yang dipahami atau diharapkan pada bentuk-bentuk bahasa tertentu, tetapi tidak terungkap. Artinya, implikatur konvensional adalah makna harfiah seperti yang dinyatakan oleh elemen kalimat secara format struktural.

Berikut adalah data implikatur konvensional dalam gelar wicara Indonesia Lawak Klub:

Tabel 1 Hasil Temuan Jenis Implikatur Konvensional

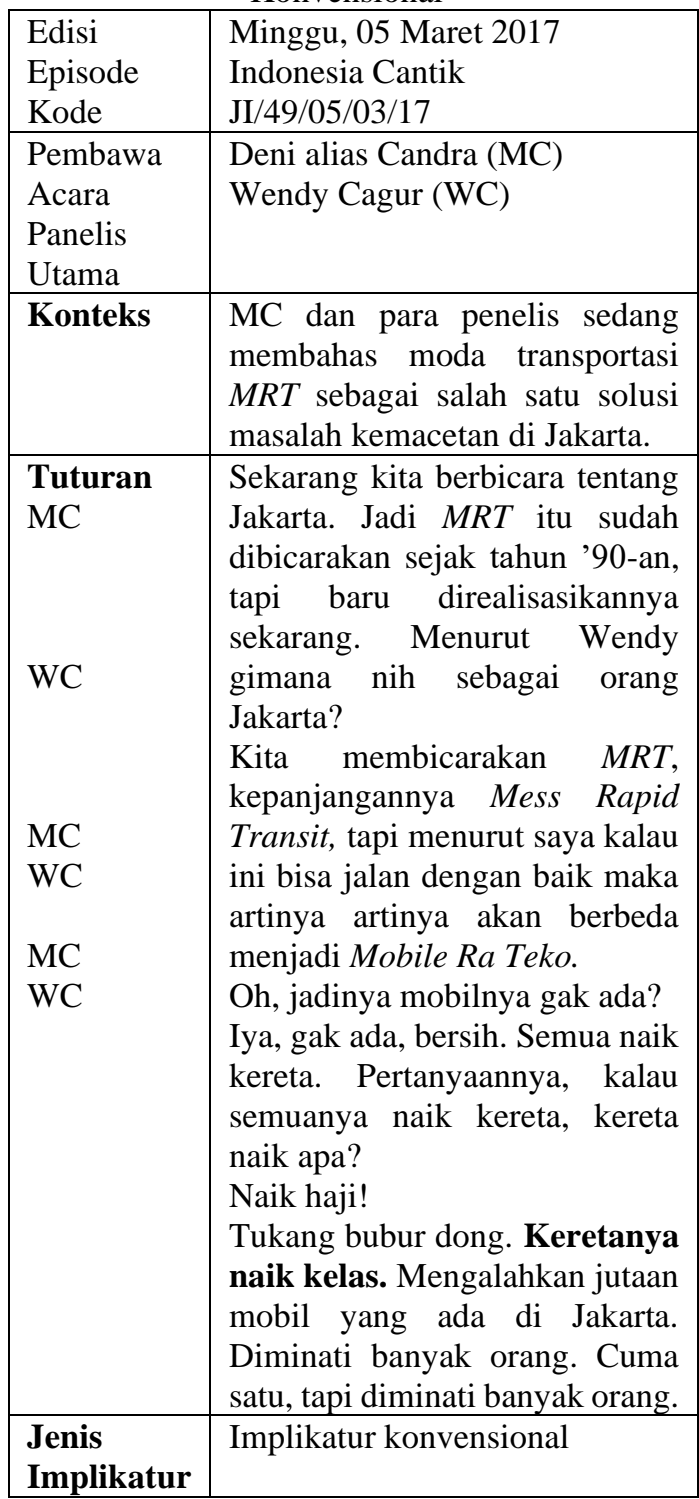




\begin{tabular}{|c|c|}
\hline isis & $\begin{array}{l}\text { Tuturan "Keretanya naik kelas" } \\
\text { yang dikatakan oleh MC } \\
\text { mengandung implikatur } \\
\text { konvensional. Hal itu karena } \\
\text { tuturan tersebut mengandung } \\
\text { makna khusus sehingga } \\
\text { menghasilkan makna tambahan. } \\
\text { Implikatur konvensional pada } \\
\text { tuturan tersebut adalah bahwa } \\
M R T \text { menjadi transportasi massa } \\
\text { yang hebat dan mempunyai } \\
\text { banyak keunggulan } \\
\text { dibandingkan } \\
\text { transportasi massa yang lainnya. }\end{array}$ \\
\hline Makna & $\begin{array}{l}\text { Tuturan "Keretanya naik kelas" } \\
\text { yang dikatakan oleh MC } \\
\text { bermakna bahwa MRT menjadi } \\
\text { transportasi massa yang hebat } \\
\text { dan mempunyai banyak } \\
\text { keunggulan dibandingkan } \\
\text { dengan transportasi massa yang } \\
\text { lainnya. }\end{array}$ \\
\hline
\end{tabular}

Berdasarkan data tersebut menjelaskan bahwa $M R T$ singkatan dari Mess Rapid Transit sedang dipersiapkan untuk menjadi salah satu solusi kemacetan di Jakarta. Penelis Wendy barasumsi bahwa moda transportasi $M R T$ ini merupakan solusi cerdas yang dapat menjadi solusi kemacetan Jakarta dibandingkan dengan moda transportasi lain yang telah ada.

Jenis implikatur yang tepat adalah implikatur konvensional, yaitu pada tuturan "Keretanya naik kelas" yang dikatakan oleh panelis Wendy. Hal itu karena dalam tuturan tersebut mempunyai makna khusus secara struktural sehingga menjadi makna tambahan secara tersirat dalam tuturan. Adapun makna yang dimaksudkan adalah bahwa $M R T$ menjadi transportasi massa yang hebat dan mempunyai banyak keunggulan dibandingkan dengan transportasi massa lain sehingga $M R T$ diperkirakan dapat menjadi solusi dari kemacatan di Jakarta.

\section{Implikatur Percakapan}

Implikatur percakapan adalah tindak ilokusi yang implikasi pragmatiknya diambil dari prinsip-prinsip percakapan. Implikatur nonkonvensional inilah yang saat ini dikenal dengan sebutan implikatur percakapan. Implikatur percakapan adalah makna yang dipahami, tetapi tidak atau kurang terungkap dalam ucapannya.

Berikut adalah data implikatur konvensional dalam gelar wicara Indonesia Lawak Klub:

Tabel 2 Hasil Temuan Jenis Implikatur Percakapan

\begin{tabular}{|c|c|}
\hline $\begin{array}{l}\text { Edisi } \\
\text { Episode } \\
\text { Kode } \\
\end{array}$ & $\begin{array}{l}\text { Sabtu, } 27 \text { Mei } 2017 \\
\text { Kejar Rezeki atau Ibadah } \\
\text { JI/74/27/05/17 }\end{array}$ \\
\hline $\begin{array}{l}\text { Pembawa } \\
\text { Acara } \\
\text { Panelis } \\
\text { Utama }\end{array}$ & $\begin{array}{l}\text { Denny alias Chandra (MC) } \\
\text { Pak Jarwo }(\mathrm{PJ})\end{array}$ \\
\hline Konteks & $\begin{array}{l}\text { Pak Jarwo sedang menjelaskan } \\
\text { bahwa rezeki jangan dikejar, } \\
\text { tetapi meminta kepada Sang } \\
\text { Pemilik Rezeki. }\end{array}$ \\
\hline $\begin{array}{l}\text { Tuturan } \\
\text { PJ }\end{array}$ & $\begin{array}{l}\text { Ibadah atau rezeki itu tidak perlu } \\
\text { dikejar, Pak Deni, tetapi berdoa } \\
\text { dan Allah meminta kita untuk } \\
\text { tidak mengejar rezeki, tetapi } \\
\text { meminta kepada Allah untuk } \\
\text { mendekatkan rezeki itu kepada } \\
\text { kita. Jangan dikejar! Saya sudah } \\
\text { lama, tujuh tahun saya di } \\
\text { Pesantren Gontor, Pak Deni. } \\
\text { Oh, di sana belajar Pak Jarwo? } \\
\text { Jualan tasbih di depan pesantren. } \\
\text { Yah, iya, kurang lucu, ya! }\end{array}$ \\
\hline $\begin{array}{l}\text { Jenis } \\
\text { Implikatur }\end{array}$ & Implikatur percakapan \\
\hline Analisis & $\begin{array}{l}\text { Tuturan "Yah, iya, kurang lucu, } \\
\text { ya!" yang dikatakan oleh } \\
\text { panelis Pak Jarwo (PJ) } \\
\text { mengandung implikatur } \\
\text { percakapan. Hal itu karena } \\
\text { tuturan tersebut selain bersifat } \\
\text { informatif juga mengandung } \\
\text { implikasi bahwa panelis PJ } \\
\text { meminta kepada para penonton } \\
\text { dan para panelis lainnya untuk } \\
\text { tertawa atas humor yang telah } \\
\text { dikatakannya. }\end{array}$ \\
\hline Makna & $\begin{array}{l}\text { Tuturan "Yah, iya, kurang lucu, } \\
\text { ya!" yang dikatakan oleh } \\
\text { panelis Pak Jarwo (PJ) selain } \\
\text { bermakna informatif juga }\end{array}$ \\
\hline
\end{tabular}




\begin{tabular}{|l|l|}
\hline mengandung implikasi bahwa \\
panelis PJ meminta kepada para \\
penonton dan para panelis \\
lainnya untuk tertawa atas \\
humor yang telah dikatakannya.
\end{tabular}

Berdasarkan data tersebut terlihat bahwa menjelaskan panelis Pak Jarwo sedang menjalaskan rezeki tidak perlu dikejar, tetapi meminta dan berdoa kepada Sang Pemilik Rezeki. Oleh karena itulah, panelis Pak Jarwo sudah selama tujuh tahun di Pesantren Gontor untuk berjualan tasbih.

Jenis implikatur yang tepat adalah implikatur percakapan pada tuturan "Yah, iya, kurang lucu, ya!" yang dikatakan oleh panelis Pak Jarwo. Peranan konteks dalam tuturan ini adalah tidak adanya tertawaan, baik dari penonton maupun panelis lainnya setelah panelis Pak Jarwo menjelaskan berhumor mengenao ketidakhubungan meminta rezeki dengan berjualan tasbih di Pesantren Gontor. Oleh karena itu, adanya implikatur percakapan karena tuturan tersebut selain bersifat informatif juga mengandung implikasi bahwa panelis PJ meminta kepada para penonton dan para panelis lainnya untuk tertawa atas humor yang telah dikatakannya.

\section{Pelanggaran Prinsip Kerja Sama}

Secara umum prinsip kerja sama terbagi dalam empat macam, prinsip kerja sama maksim kualitas, kerja sama maksim kuantitas, kerja sama maksim relevansi, dan kerja sama maksim cara. Dalam gelar wicara Indonesia Lawak Klub ditemukan sebanyak 23 data atau 19,2\% pelanggaran prinsip kerja sama maksim kualitas, 60 data atau 50\% pelanggaran prinsip kerja sama maksim kuantitas, 27 data atau $22,5 \%$ pelanggaran prinsip kerja sama maksim relevansi, dan 10 data atau 8,3\% pelanggaran prinsip kerja sama maksim cara.

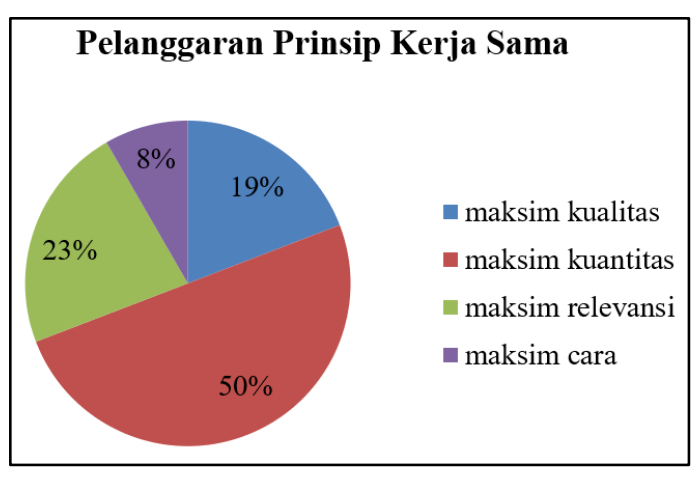

Grafik 2 Hasil Temuan Pelanggaran Prinsip Kerja Sama

\section{Maksim Kualitas}

Maksim kualitas mengharuskan seorang penutur dapat menyampaikan sesuatu yang nyata dan sesuai fakta, tidak berasumsi sendiri. Berikut adalah data pelanggaran prinsip kerja sama maksim kualitas dalam gelar wicara Indonesia Lawak Klub:

Tabel 3 Hasil Temuan Pelanggaran Maksim Kualitas

\begin{tabular}{|c|c|}
\hline $\begin{array}{l}\text { Edisi } \\
\text { Episode } \\
\text { Kode } \\
\end{array}$ & $\begin{array}{l}\text { Minggu, } 14 \text { Mei } 2017 \\
\text { Cinta dan Komitmen } \\
\text { PKS/66/14/05/17 }\end{array}$ \\
\hline $\begin{array}{l}\text { Pembawa } \\
\text { Acara } \\
\text { Panelis } \\
\text { Utama }\end{array}$ & $\begin{array}{l}\text { Deni alias Candra (MC) } \\
\text { Yuanita Christiani (YC) }\end{array}$ \\
\hline Konteks & $\begin{array}{l}\text { MC dan para panelis sedang } \\
\text { bermain games truth or dare. } \\
\text { Panelis Yuanita Christiani } \\
\text { (YC) mendapat giliran } \\
\text { pertama dengan pilihan truth, } \\
\text { yang berarti panelis YC harus } \\
\text { berbicara jujur mengenai kisah } \\
\text { cintanya. }\end{array}$ \\
\hline $\begin{array}{l}\text { Tuturan } \\
\text { MC }\end{array}$ & 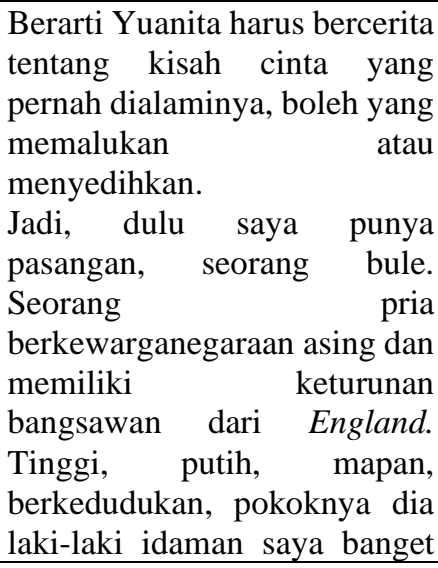 \\
\hline
\end{tabular}




\begin{tabular}{|c|c|}
\hline & $\begin{array}{l}\text { dan pengen banget bersama } \\
\text { dengan dia, Pak. Dia juga } \\
\text { sudah bertemu dengan orang } \\
\text { tua saya dan saya juga sudah } \\
\text { bertemu dengan orang tua dia. } \\
\text { Semuanya senang dan } \\
\text { semuanya restu. Semua teman } \\
\text { saya yang saya kenalkan juga } \\
\text { setuju banget saya sama dia, } \\
\text { Pak. Saya sih mau sama dia, } \\
\text { Pak, tapi ada satu sayangnya. } \\
\text { Sayang benget, itu semua } \\
\text { dalam mimpi saya, Pak. }\end{array}$ \\
\hline $\begin{array}{l}\text { Pelanggaran } \\
\text { PKS }\end{array}$ & $\begin{array}{l}\text { Pelanggaran prinsip kerja } \\
\text { sama maksim kualitas }\end{array}$ \\
\hline Analisis & $\begin{array}{l}\text { Tuturan "Sayang benget, itu } \\
\text { semua dalam mimpi saya, } \\
\text { Pak." yang dikatakan panelis } \\
\text { Yuanita Christiani (YC) } \\
\text { mengandung pelanggaran } \\
\text { prinsip kerja sama maksim } \\
\text { kualitas. Hal itu karena tuturan } \\
\text { tersebut tidak mengandung } \\
\text { sebuah kebenaran, melainkan } \\
\text { hanya sebuah khayalan } \\
\text { panelis. }\end{array}$ \\
\hline Makna & $\begin{array}{l}\text { Tuturan "Sayang benget, itu } \\
\text { semua dalam mimpi saya, } \\
\text { Pak." yang dikatakan panelis } \\
\text { Yuanita Christiani (YC) } \\
\text { bermakna secara implisit } \\
\text { sebuah kesedihan panelis } \\
\text { karena kisah cinta yang } \\
\text { diimpikannya tersebut } \\
\text { hanyalah sebuah khayalannya. }\end{array}$ \\
\hline
\end{tabular}

\section{Berdasarkan data tersebut} menjelaskan bahwa panelis Yuanita Christiani menceritakan kisah cintanya yang menyedihkan. Panelis Yuanita mempunyai hubungan cinta dengan seorang bangsawan dari Inggris, tampan, mapan, dan baik dalam hal lainnya, tetapi ada satu hal yang membuatnya tidak bisa bersatu, yaitu semua cerita tersebut hanyalah sebuah mimpi, tidak nyata.

Pelanggaran prinsip kerja sama yang tepat adalah pelanggaran prinsip kerja sama pada maksim kualitas. Hal itu karena panelis menceritakan suatu hal yang tidak nyata dan tidak benar. Panelis menceritakan hal yang sebenarnya adalah sebuah mimpi dan harapannya.

\section{Maksim Kuantitas}

Maksim kuantitas, seorang penutur memberikan informasi yang cukup, relative memadai, dan seinformatif mungkin. Berikut adalah data pelanggaran prinsip kerja sama maksim kuantitas dalam gelar wicara Indonesia Lawak Klub:

Tabel 4 Hasil Temuan Pelanggaran Maksim Kuantitas

\begin{tabular}{|c|c|}
\hline $\begin{array}{l}\text { Edisi } \\
\text { Episode } \\
\text { Kode }\end{array}$ & $\begin{array}{l}\text { Sabtu, } 18 \text { Februari } 2017 \\
\text { Spesial Armada } \\
\text { PKS/15/18/02/17 }\end{array}$ \\
\hline $\begin{array}{l}\text { Pembawa } \\
\text { Acara } \\
\text { Panelis } \\
\text { Utama }\end{array}$ & $\begin{array}{l}\text { Deny alias Candra }(\mathrm{MC}) \\
\text { Kirana }(\mathrm{Ki})\end{array}$ \\
\hline Konteks & $\begin{array}{l}\text { MC dan para panelis sedang } \\
\text { mengulas lagu Armada Band } \\
\text { yang berjudul Mau Dibawa } \\
\text { Kemana. }\end{array}$ \\
\hline $\begin{array}{l}\text { Tuturan } \\
\mathrm{MC} \\
\mathrm{Ki}\end{array}$ & $\begin{array}{l}\text { Kalau Kirana, gimana ini } \\
\text { Kirana? Gimana sebagai } \\
\text { penikmat musik. } \\
\text { Saya mendengarkan lagu ini } \\
\text { tuh, sakit hati saya. Pedih. } \\
\text { Saya mau bicara soal musik } \\
\text { dan perasaan, ya karena musik } \\
\text { yang kita dengarkan sehari- } \\
\text { hari apabila sesuai dengan } \\
\text { keadaan hati kita itu akan kena } \\
\text { sekali. Seperti lagu ini, rasanya } \\
\text { pedih. Jadi, ya, Pak ternyata } \\
\text { bukan cuma gigi yang bisa } \\
\text { dipalsukan, tetapi perasaan } \\
\text { juga. }\end{array}$ \\
\hline $\begin{array}{l}\text { Pelanggar } \\
\text { PKS }\end{array}$ & $\begin{array}{l}\text { Pelanggaran prinsip kerja } \\
\text { sama maksim kuantitas }\end{array}$ \\
\hline Analisis & $\begin{array}{l}\text { Tuturan yang dikatakan oleh } \\
\text { panelis Kirana (Ki) banyak } \\
\text { mengandung pelanggaran } \\
\text { prinsip kerja sama pada } \\
\text { maksim kuantitas. Hal } \\
\text { tersebut karena MC hanya } \\
\text { bertanya pendapatnya } \\
\text { mengenai lagu Armada Band } \\
\text { yang berjudul Mau Dibawa } \\
\text { Kemana, tetapi selain } \\
\text { berkomentar, panelis Ki juga } \\
\text { menyelipkan curahan hatinya } \\
\text { tentang pengalaman buruknya } \\
\text { yang sama persis seperti lagu } \\
\text { tersebut. }\end{array}$ \\
\hline Mak & $\begin{array}{l}\text { Tuturan yang dikatakan oleh } \\
\text { panelis Kirana (Ki) tidak }\end{array}$ \\
\hline
\end{tabular}




\begin{tabular}{|l|l|}
\hline hanya bermakna informatif, \\
tetapi juga menyelipkan \\
curahan hatinya tentang \\
pengalaman buruknya yang \\
sama persis seperti lagu \\
tersebut. Juga pada tuturan \\
terakhir panelis Ki \\
mengingatkan dan menasihati \\
kawula muda untuk selalu \\
berhati-hati pada kepalsuan \\
cinta dalam menjalin suatu \\
hubungan.
\end{tabular}

Berdasarkan data tersebut menjelaskan bahwa panelis Kirana merasa selalu sedih dan sakit hati ketika mendengarkan lagu Armada Band yang berjudul Mau Dibawa Kemana karena lagu tersebut sesuai dengan pengalaman kisah cintanya yang tidak berakhir bahagia.

Pelanggaran prinsip kerja sama yang tepat adalah pelanggaran prinsip kerja sama pada maksim kuantitas. Hal itu karena panelis tidak memberikan jawaban yang berlebihan dan kurang informatif. Tuturan yang disampaikan oleh panelis tersebut tidak hanya berupa jawaban atas pertanyaan MC, tetapi dia juga menyelipkan curahan hatinya tentang pengalaman buruknya yang sama persis seperti lagu tersebut.

\section{Maksim Relevansi}

Maksim relevansi, seorang penutur harus dapat menyampaikan sesuatu secara relevan atau sesuai dan mempunyai hubungan yang sama dengan topik pembicaraan. Berikut adalah data pelanggaran prinsip kerja sama maksim relevansi dalam gelar wicara Indonesia Lawak Klub:

Tabel 5 Hasil Temuan Pelanggaran Maksim Relevansi

\begin{tabular}{|c|c|}
\hline $\begin{array}{l}\text { Edisi } \\
\text { Episode } \\
\text { Kode } \\
\end{array}$ & $\begin{array}{l}\text { Minggu, } 16 \text { April } 2017 \\
\text { Impersonator } \\
\text { PKS/31/16/04/17 } \\
\end{array}$ \\
\hline $\begin{array}{l}\text { Pembawa } \\
\text { Acara } \\
\text { Panelis } \\
\text { Utama }\end{array}$ & $\begin{array}{l}\text { Deni alias Candra (MC) } \\
\text { Rizky Inggar (Anggun C. } \\
\text { Sasmi/RI) }\end{array}$ \\
\hline
\end{tabular}

\begin{tabular}{|c|c|}
\hline Ko & $\begin{array}{l}\text { MC dan para panelis sedang } \\
\text { membahas motivasi go } \\
\text { international Anggun C. Sasmi } \\
\text { yang diimpersonatorkan oleh } \\
\text { Rizky Inggar. }\end{array}$ \\
\hline $\begin{array}{l}\text { Tuturan } \\
\text { MC } \\
\text { RI } \\
\text { MC } \\
\text { RI }\end{array}$ & $\begin{array}{l}\text { Jadi, siapa yang mengispirasi } \\
\text { nih? } \\
\text { Motivasi saya untuk go } \\
\text { international adalah saya } \\
\text { ingin menyaingi korupsi di } \\
\text { Indonesia. } \\
\text { Waaahhh,....! } \\
\text { Karena Indonesia termasuk } \\
\text { ke dalam negara yang } \\
\text { peringkat ke-90 dari 176 } \\
\text { negara. Korupsi aja bisa go } \\
\text { international, masa Anggun } \\
\text { C. Sasmi ga bisa! }\end{array}$ \\
\hline $\begin{array}{l}\text { Pelanggatan } \\
\text { PKS }\end{array}$ & $\begin{array}{l}\text { Pelanggaran prinsip kerja sama } \\
\text { maksim relevansi }\end{array}$ \\
\hline Ana & $\begin{array}{l}\text { Tuturan dari RI mengandung } \\
\text { pelanggaran prinsip kerja sama } \\
\text { maksim relevansi } r \text { dan } \\
\text { kuantitas. } \\
\text { pelanggaran pada maksim } \\
\text { relevansi karena } \\
\text { menanyakan perihal siapa } \\
\text { (mengacu pada orang) yang } \\
\text { telah menginspirasinya, tetapi } \\
\text { jawaban RI justru perihal apa } \\
\text { (kasus korupsi) yang telah } \\
\text { memotivasinya. Hal tersebut } \\
\text { mengandung } \\
\text { ketidaknyambungan } \\
\text { ketidakberhubungan. Kedua, } \\
\text { pelanggaran pada maksim } \\
\text { kuantitas karena jawaban yang } \\
\text { dilontarkan oleh RI terlalu } \\
\text { panjang berupa pemberian } \\
\text { informasi mengenai tingginya } \\
\text { peringkat kasus korupsi } \\
\text { Indonesia di kancah } \\
\text { internasional. }\end{array}$ \\
\hline Makna & $\begin{array}{l}\text { Makna yang terkandung dalam } \\
\text { tuturan RI adalah berupa } \\
\text { sindiran dan pengungkapan } \\
\text { rasa malu dari kehebatan kasus } \\
\text { korupsi di Indonesia yang telah } \\
\text { go international dan bahkan } \\
\text { mendapatkan peringkat tinggi } \\
\text { di kancah internasional. }\end{array}$ \\
\hline
\end{tabular}

Berdasarkan data tersebut menjelaskan bahwa panelis Rizky Inggar yang berimpersonator sebagai Anggun C. Sasmi bercerita tentang motivasinya 
untuk go international, yaitu ingin menyaingi korupsi di Indonesia. Hal tersebut karena Indonesia termasuk ke dalam negara yang peringkat ke-90 dari 176 negara.

Pelanggaran prinsip kerja sama yang tepat adalah pelanggaran prinsip kerja sama pada maksim relevansi. Hal itu karena panelis memberikan jawaban yang tidak relevan atau tidak sesuai dan memiliki hubungan dengan pertanyaan MC menanyakan perihal siapa (mengacu pada orang) yang telah menginspirasinya, tetapi jawaban RI justru perihal apa (kasus korupsi) yang telah memotivasinya.

\section{Maksim Cara}

Maksim cara, seorang penutur harus dapat menyampaikan sesuatu secara jelas, tidak bias, tidak taksa, dan tidak ambigu. Berikut adalah data pelanggaran prinsip kerja sama maksim cara dalam gelar wicara Indonesia Lawak Klub:

Tabel 6 Hasil Temuan Pelanggaran Maksim Cara

\begin{tabular}{|l|l|}
\hline Edisi & Minggu, 26 Februari 2017 \\
Kode & Cerita Cinta \\
PKS/20/26/02/17
\end{tabular}

\begin{tabular}{|l|l|}
\hline & prinsip kerja sama pada \\
maksim cara. Hal tersebut \\
karena kalimat tersebut \\
mengandung makna yang \\
ambigu, ketidakjelasan, dan \\
bias. Keambiguan tersebut \\
terletak pada kata ke mana. \\
Kata ke mana seharusnya \\
digunakan dalam kalimat \\
tanya. Jadi, kalimat jodoh gak \\
akan ke mana berarti \\
menyatakan tidak akan pergi \\
ke mana (tempat). \\
\hline Kalimat "jodoh gak akan ke \\
mana" sebenarnya bermakna \\
ambigu jika dikaji \\
berdasarkan ilmu semantik, \\
tetapi berdasarkan konteks, \\
kalimat terebut bermakna \\
seseorang yang menjadi jodoh \\
kita pasti akan bersama kita \\
sejauh apa pun jaraknya.
\end{tabular}

Berdasarkan data tersebut menjelaskan panelis Awwe percaya bahwa seseorang yang ditakdirkan berjodoh maka akan bertemu dan bersatu. Pelanggaran prinsip kerja sama yang tepat adalah pelanggaran prinsip kerja sama pada maksim cara. Hal itu karena kalimat tersebut mengandung makna yang ambigu, ketidakjelasan, dan bias. Keambiguan tersebut terletak pada kata ke mana. Kata ke mana seharusnya digunakan dalam kalimat tanya. Jadi, kalimat jodoh gak akan ke mana berarti menyatakan tidak akan pergi ke mana (tempat).

\section{SIMPULAN}

Berdasarkan pembahasan tersebut, dapat disimpulkan bahwa ditemukan 100 percakapan dari 18 episode yang diteliti. Dari 100 percakapan tersebut mengandung 100 data jenis implikatur dan 120 data pelanggaran prinsip kerja sama. 100 data jenis implikatur terdiri atas 52 data atau $52 \%$ implikatur konvensional dan 48 data atau $48 \%$ implikatur percakapan. Sedangkan, 120 data pelanggaran prinsip kerja sama terdiri atas 23 data atau 19,2\% 
pelanggaran prinsip kerja sama maksim kualitas, 60 data atau 50\% pelanggaran prinsip kerja sama maksim kuantitas, 27 data atau $22,5 \%$ pelanggaran prinsip kerja sama maksim relevansi, dan 10 data atau 8,3 pelanggaran prinsip kerja sama maksim cara.

\section{DAFTAR PUSTAKA}

Brown, G., \& Yule, G. (1983). Discourse analysis. Cambridge: Cambridge university press.

Fauziah, M. T., Emzir, \& Lustyantie, N. (2018). Pelanggaran prinsip kerja ssama dalam tuturan diskusi kelas Bahasa Indonesia. JP-BSI (Jurnal Pendidikan Bahasa Dan Sastra Indonesia), 3(2), 51-57. Retrieved from http://journal.stkipsingkawang.a c.id/index.php/JP-

BSI/article/download/722/pdf.

Grice, H. P. (1991). Logic and conversation (Steven Davis, Ed.). New York: Oxford.

Kridalaksana, H. (1985). Tata bahasa deskriptif bahasa Indonesia (Sintaksis). Jakarta: Pusat
Pembinaan dan Pengembangan Bahasa.

Krippendorff, K. (1991). Analisis isi: Pengantar teori dan metodologi (F. Wajidi, Ed.). Jakarta: Rajawali.

Levinson, S. C. (1983). Pragmatics. In Cambridge UK. Cambridge: Cambridge University Press.

Nadir, F. X. (2013). Pragmatik dan penelitian pragmatik. Yogyakarta: Graha Ilmu.

Wahyuningsih, H., \& Rafli, Z. (2017). Implikatur percakapan dalam stand up comedy 4. BAHTERA: Jurnal Pendidikan Bahasa Dan Sastra, 16(2), 139-153. Retrieved from http://journal.unj.ac.id/unj/index .php/bahtera/article/view/4313

Wijana, I. D. P. (2003). Kartun: Studi tentang permainan bahasa. Yogyakarta: Ombak.

Yule, G. (1996). Pragmatics: Oxford University Press. Oxford. 